\title{
Macro mineral and trace element content of pangola grass and other forages in Guadeloupe (F.W.I.) $)^{1,2}$
}

\author{
Gilles Aumont ${ }^{3}$, Alain Xandé $e^{3}$ and Jacques Bellanger ${ }^{4}$
}

J. Agric. Univ. P.R. 80(1-2):21-35 (1996)

\begin{abstract}
Macro minerals and trace elements of ruminant feeding interest were determined in forages from three regions of Guadeloupe (French West Indies) region $A$ - calcareous area with Vertisols overlying coral limestone with a marked dry season; region B - acid soils area with Vertisols and Oxisols and a mild dry season; region $\mathrm{C}$ - ferrallitic soils area (Oxisols) with a short dry season. Samples of pangola grass and natural pastures were collected at five locations within each region, during both the rainy and dry seasons, at two stages of regrowth ( 28 vs. 42 d). The region of sampling and the type of forage were the main sources of variation of the macro mineral and trace element content of forages. The samples of pangola grown in calcareous regions had lower concentrations of phosphorus, magnesium, copper, zinc, manganese, and selenium than samples collected in other regions: region $A$ - $2.18 \mathrm{~g} \mathrm{P} / \mathrm{kg} \mathrm{DM}, 1.49 \mathrm{~g} \mathrm{Mg} / \mathrm{kg}$ DM, $6.75 \mathrm{mg} \mathrm{Cu} / \mathrm{kg} \mathrm{DM}, 26.82 \mathrm{mg} \mathrm{Zn/kg} \mathrm{DM,}$ $53.00 \mathrm{mg} \mathrm{Mn} / \mathrm{kg} \mathrm{DM}, 0.11 \mathrm{mg}$ Se $/ \mathrm{kg}$ DM; region B - $3.31 \mathrm{~g} \mathrm{P} / \mathrm{kg} \mathrm{DM}, 1.51 \mathrm{~g} \mathrm{Mg} /$ $\mathrm{kg} \mathrm{DM}, 8.75 \mathrm{mg} \mathrm{Cu} / \mathrm{kg} \mathrm{DM}, 50.40 \mathrm{mg} \mathrm{Zn} / \mathrm{kg} \mathrm{DM}, 226.00 \mathrm{mg} \mathrm{Mn} / \mathrm{kg} \mathrm{DM}, 0.17$ $\mathrm{mg} \mathrm{Se} / \mathrm{kg}$ DM; region C - $2.73 \mathrm{~g} \mathrm{P} / \mathrm{kg} \mathrm{DM}, 1.45 \mathrm{~g} \mathrm{Mg} / \mathrm{kg} \mathrm{DM}, 7.69 \mathrm{mg} \mathrm{Cu} / \mathrm{kg}$ DM, 32.75 mg Zn/kg DM, 284.00 mg Mn/kg DM, $0.15 \mathrm{mg}$ Se/kg DM. Phosphorus, copper, zinc and selenium contents of forages were frequently below critical nutritional values in each region of sampling. Natural savana forages presented lower phosphorus, magnesium, sodium, copper and zinc contents than those of pangola. The risks of deficiencies in phosphorus, copper, zinc and selenium for the grazing ruminant in the different regions of Guadeloupe are discussed.
\end{abstract}

Key words: pangola, forages, West Indies, minerals, trace elements

\section{RESUMEN}

Contenido de minerales y oligoelementos en pangola y otros forrajes en Guadalupe

El contenido de minerales y oligoelementos en forrajes para alimentar rumiantes se estudió en tres regiones de Guadalupe: región A - suelo Verti-

'Manuscript submitted to Editorial Board 5 March 1993.

"We are grateful to M. Lamand for providing facilities and M. Chenost for preparing the manuscript. Thanks are due to C. Lab, M. Mignon, J. Moinard, J. C. Tressol for their technical assistance, and to the farmers who let us use their fields.

${ }^{3}$ Institut National de la Recherche Agronomique, Unité de Recherches Zootechniques, BP 515, 97165 Pointe à Pitre Cedex, Guadeloupe (F. W. I.).

'Institut National de la Recherche Agronomique, Laboratoire des Maladies Nutritionnelles, 63122 St. Genès Champenelle, France. 
sol calcáreo con una estación muy seca; región B - zona de suelos Vertisol y Oxisol con una estación seca corta; región $\mathrm{C}$ - suelo ferralitico (Oxisol) con una estación seca muy corta. Las muestras de pangola y pastos naturales se recogieron en cinco lugares distintos de las regiones A, B, y C durante la estación de sequia y la estación húmeda a dos niveles de crecimiento ( 28 vs. 42 dias). Las zonas en que se escogieron las muestras y el tipo de forrajes son las principales causas de variaciones en el contenido de minerales y oligoelementos de los forrajes. Las muestras de pangola y pastos naturales en los suelos calcáreos contenian menos $\mathrm{P}, \mathrm{Mg}, \mathrm{Cu}, \mathrm{Zn}$, Mn y Se que las muestras tomadas en otras regiones: región $\mathrm{A}-2.18 \mathrm{~g} \mathrm{P} / \mathrm{kg}$ DM, $1.49 \mathrm{~g} \mathrm{Mg} / \mathrm{kg} \mathrm{DM}, 6.75 \mathrm{mg}$ Cu/ $\mathrm{kg} D M, 26.82 \mathrm{mg} \mathrm{Zn} / \mathrm{kg} \mathrm{DM}, 53.00 \mathrm{mg} \mathrm{Mn} /$ $\mathrm{kg} \mathrm{DM,} 0.11 \mathrm{mg} \mathrm{Se} / \mathrm{kg}$ DM; región B - $3.31 \mathrm{~g} \mathrm{P} / \mathrm{kg} \mathrm{DM,} 1.51 \mathrm{~g} \mathrm{Mg} / \mathrm{kg} \mathrm{DM,} 8.75$ $\mathrm{mg} \mathrm{Cu} / \mathrm{kg} \mathrm{DM,} 50.40 \mathrm{mg} \mathrm{Zn/kg} \mathrm{DM,} \mathrm{226.00} \mathrm{mg} \mathrm{Mn/kg} \mathrm{DM,} 0.17 \mathrm{mg} \mathrm{Se} / \mathrm{kg} \mathrm{DM;}$ región C $-2.73 \mathrm{~g} \mathrm{P} / \mathrm{kg} \mathrm{DM}, 1.45 \mathrm{~g} \mathrm{Mg} / \mathrm{kg} \mathrm{DM}, 7.69 \mathrm{mg} \mathrm{Cu} / \mathrm{kg} \mathrm{DM}, 32.75 \mathrm{mg} \mathrm{Zn} /$ $\mathrm{kg} \mathrm{DM}, 284.00 \mathrm{mg} \mathrm{Mn} / \mathrm{kg}$ DM, $0.15 \mathrm{mg}$ Se/ $\mathrm{kg}$ DM. EI contenido de P, Cu, Zn y Se de los forrajes es muy a menudo inferior del nivel critico. Los pastos naturales tienen contenidos más bajos que la pangola. Se analizan los riesgos de deficiencias en $\mathrm{P}, \mathrm{Cu}, \mathrm{Zn}$ y Se para los animales que pastan en las diferentes regiones de Guadalupe.

\section{INTRODUCTION}

Dietary mineral imbalances (deficiencies or toxicities) have long been held responsible for troubles among grazing ruminants in tropical countries (McDowell, 1976; Minson, 1990). In these countries, beef cattle and sheep or goats depend almost entirely upon forages to supply their mineral requirements (Osburn, 1976). Futhermore, forages grown on tropical soils are often deficient in numerous macro minerals and trace elements required by the animals (McDowell, 1976; Minson, 1990). Wasting disease, pica, loss of appetite, low fertility and poor hair condition are the most suggestive clinical signs of macro mineral and trace element imbalances. Subclinical deficiencies, however, might affect the productivity of livestock breeds without any clear clinical symptoms (Underwood, 1981). Thus, a knowledge of the macro mineral and trace element composition in forage is required to make a survey of mineral deficiencies and to define macro mineral and trace element requirements for grazing ruminants.

Many factors interact to affect the macro mineral contents of plants. These include soil and climate, plant species, age of regrowth and pasture management (Minson, 1990). Numerous studies with potted plants have been conducted, but the macro mineral contents of forages have rarely been investigated directly in pastures of Caribbean areas. The islands of Guadeloupe (lat $16^{\circ} 0^{\prime} \mathrm{N}$, lon $61^{\circ} 3^{\prime}$ ) in the Caribbean provided an opportunity to evaluate different soil/climate complexes frequently encountered in Caribbean areas and Latin America. These include alkaline soil with a marked dry season, alkaline soil with a medium dry season and acid soil with a short dry season (Colmet-Daage and Lagache, 1969). The main purpose of this study was to investigate 
the influences of soil/climate complexes, and the season and age of pasture regrowth on the macro mineral and trace element contents of pangola (Digitaria decumbens) and natural savana in Guadeloupe. Pangola grass was chosen as a reference forage since it is the most frequently planted forage in the French West Indies.

\section{MATERIALS AND METHODS}

Three regions of sampling were chosen for their soil/climate complexes (Table 1). In each region, both cattle and small ruminants are reared. Region A was characterized by alkaline soil (calcomagnesian Vertisols overlying coral limestones), low annual rainfall (1,200 to $1,700 \mathrm{~mm} /$ year) with a marked dry season. Region $\mathrm{C}$ presented acid soils (ferrallitic soil cover developed on highly weathered andesitic volcanic deposits), high annual rainfall (2,000 to $4,000 \mathrm{~mm} / \mathrm{yr})$ with a poorly defined dry season. The particulars of the soil/climate complexes in region $B$ were intermediate between those of regions $A$ and $C$ (Table 1).

Samples of Digitaria decumbens were collected at five sites within each region at two stages of regrowth ( 28 and 42 days) during two seasons (rainy and dry). Sixty samples of pangola grass were collected. Since the pangola grass, under some pasture management practices, tends to develop large amounts of dry matter (DM) as stolon, special care was taken to collect only stalks and leaves of the plant. There is no history of fertilizer usage at the five sampling locations.

Close to the plots sampled for pangola, seven, four and five samples of natural pasture (savana) were collected, respectively, for regions $A$, $\mathrm{B}$ and $\mathrm{C}$ during both the dry and the rainy season, but it was impossible to determine the age of regrowth of these samples. The main species were Dichanthium aristatum for region A, Dichanthium aristatum and D. annulatum for region $\mathrm{B}$, and Axonopus compressus for region $\mathrm{C}$ (Table 1, Fournet and Monestiez, 1987).

The samples were dried in a an oven at $60^{\circ} \mathrm{C}$ (max) for 48 hours. Then they were ground and stored until analysis. Calcium (Ca), phosphorus $(\mathrm{P})$, magnesium $(\mathrm{Mg})$, sodium $(\mathrm{Na})$ and potassium $(\mathrm{K})$ were determined after a sole dry ashing. Samples of $0.5 \mathrm{~g} \mathrm{DM}$ were ashed overnight at $500^{\circ} \mathrm{C}$ in a porcelain dish. Ashes were transferred to a beaker where silica was unsolubilized with hydrochloric acid solution $(6 \mathrm{~N})$ for $1 \mathrm{~h}$ until dry. Pyrophosphate, polyphosphate and metaphosphate salts were hydrolyzed at boiling point for $30 \mathrm{~min}$ with a nitric acid solution $(1.5 \mathrm{~N})$. The solution was filtered into a 50 -ml flask and the filter was washed three to four times with warm water. Calcium, $\mathrm{Mg}, \mathrm{Na}$ and $\mathrm{K}$ were determined by atomic absorption spectrometry of 
TABLE 1.-Climate, soil and botanical characteristics of the sampling regions for the determination of macro mineral and trace element contents of forages of Guadeloupe (F.W. I.).

\begin{tabular}{|c|c|c|c|}
\hline Regions of sampling & Region A & Region B & Region C \\
\hline \multirow[t]{2}{*}{ Islands } & $\begin{array}{l}\text { Western of Grande Terre and } \\
\text { Marie Galante }\end{array}$ & Eastern of Grande Terre & $\begin{array}{l}\text { Northern and western of Basse } \\
\text { Terre }\end{array}$ \\
\hline & & Climatology & \\
\hline Annual rainfall & 1,100 to 1,400 & 1,600 to 2,000 & 2,000 to 4,000 \\
\hline Dry season duration (month) & 5 to 6 & 3 to 5 & 3 to 5 \\
\hline \multirow[t]{2}{*}{ Dry season monthly rainfall (mm) } & 25 to 70 & 50 to 150 & 100 to 200 \\
\hline & & Soil properties & \\
\hline Type of soil & Vertisol & Oxisols and Vertisols & Oxisols and Andosols \\
\hline $\mathrm{pH}$ & 7.2 to 8.6 & 6.0 to 7.0 & 4.5 to 6.0 \\
\hline C.E. C. (meq $/ 100 \mathrm{~g})$ & 50 to 80 & 30 to 50 & 3 to 15 \\
\hline \multirow[t]{2}{*}{ Insolubility of phosphorus } & high & medium & low \\
\hline & \multicolumn{3}{|c|}{ Botanical composition of samples ${ }^{2}$} \\
\hline Reference forage & Digitaria decumbens & Digitaria decumbens & Digitaria decumbens \\
\hline \multirow[t]{5}{*}{ Natural savana samples } & Dichanthium aristatum & Dichanthium aristatum & Axonopus compressus \\
\hline & D. annulatum & Dichanthium annulatum & Paspalum conjugatum \\
\hline & Schenolaphrum secudatum & Schenolaphrum secudatum & Echninochloa spp. \\
\hline & Sida ciliaris & Sida ciliaris & Panicum laxum \\
\hline & Bothriochloa pretusa & Digitaria decumbens (sparced) & Paspalum districhum \\
\hline
\end{tabular}

IFrom Colmet-Daage (1969).

2From Fournet and Monestiez (1987). 
ash solutions after dilution and addition of lanthanum salts for $\mathrm{Ca}$ and $\mathrm{Mg}$, and addition of cesium salts for $\mathrm{Na}$ and $\mathrm{K}$. Phosphorus was determined by the reaction of Masson (yellow phospho-vanado molybdate complex). Sulphur (S) was determined after dry ashing in an induction furnace, by titration with a potassium iodate solution. Copper $(\mathrm{Cu})$, manganese $(\mathrm{Mn})$ and zinc $(\mathrm{Zn})$ were determined by atomic absorption spectrometry after wet ashing, according to the methods of Bellanger (1971). Cobalt (Co) was determined by atomic absorption spectrometry after dry ashing (Hocquellet, 1974). Iodine (I) determinations were performed in accordance with Sandell and Kolthoff reaction, after alkaline ashing (Bellanger et al., 1979). Molybdenum (Mo) was determined according to the method of Duval (1971), and selenium (Se) wet ashing by fluorimetry (Lamand, 1969).

All analyses were performed with SAS software (SAS, 1987). The normality of variable distribution was assessed with the skewness and kurtosis tests. Logarithm transformation was used to normalize the trace element content of forage variables. In a first step, macro mineral and trace element contents of Digitaria decumbens were analyzed with the following model:

$$
Y_{i j k}=I+R_{i}+S_{j}+A_{k}+e_{i j k}
$$

where $Y_{i j \mathrm{k}}$ was the macro mineral and trace element variables, $R_{i}$ was the region of sampling effect, $S_{j}$ was the season of sampling effect and $A_{k}$ the age regrowth effect $\left(I=\right.$ intercept and $e_{i j k}=$ residual error $)$. Least square means are given in Tables 2 and 3.

In a second step, the macro mineral and trace element contents of all samples (pangola plus savana) were analyzed with the following model:

$$
Y_{i j k}=I+R_{i}+S_{j}+N_{k}+N_{j} * R_{k}+e_{i j k}
$$

where $R_{i}$ was the region of sampling effect, $S_{j}$ was the season of sampling effect and $N_{k}$ the nature of forages effect $\left(I=\right.$ intercept and $e_{i j k}=$ residual error). Least square means of $N_{i}{ }^{*} R_{k}$ are given in Tables 4 and 5 .

\section{RESULTS}

The region of sampling was the main source of variation for $\mathrm{P}, \mathrm{Ca}$, $\mathrm{Mg}, \mathrm{S}$ and $\mathrm{Na}$ contents of Digitaria decumbens (Table 2). The P content of samples collected in the calcareous regions was lower than those of the other regions, whereas the Ca content was higher $(\mathrm{P}=0.01$; Table 2 ). Season of sampling and age of regrowth only minimally affected the macro mineral contents of pangola. The $\mathrm{P}$ and $\mathrm{Mg}$ content values were frequently below the critical limits, particularly in region $\mathrm{A}$, whereas 
TABLE 2.-Macro mineral contents of Digitaria decumbens collected in Guadeloupe (F. W. I.).

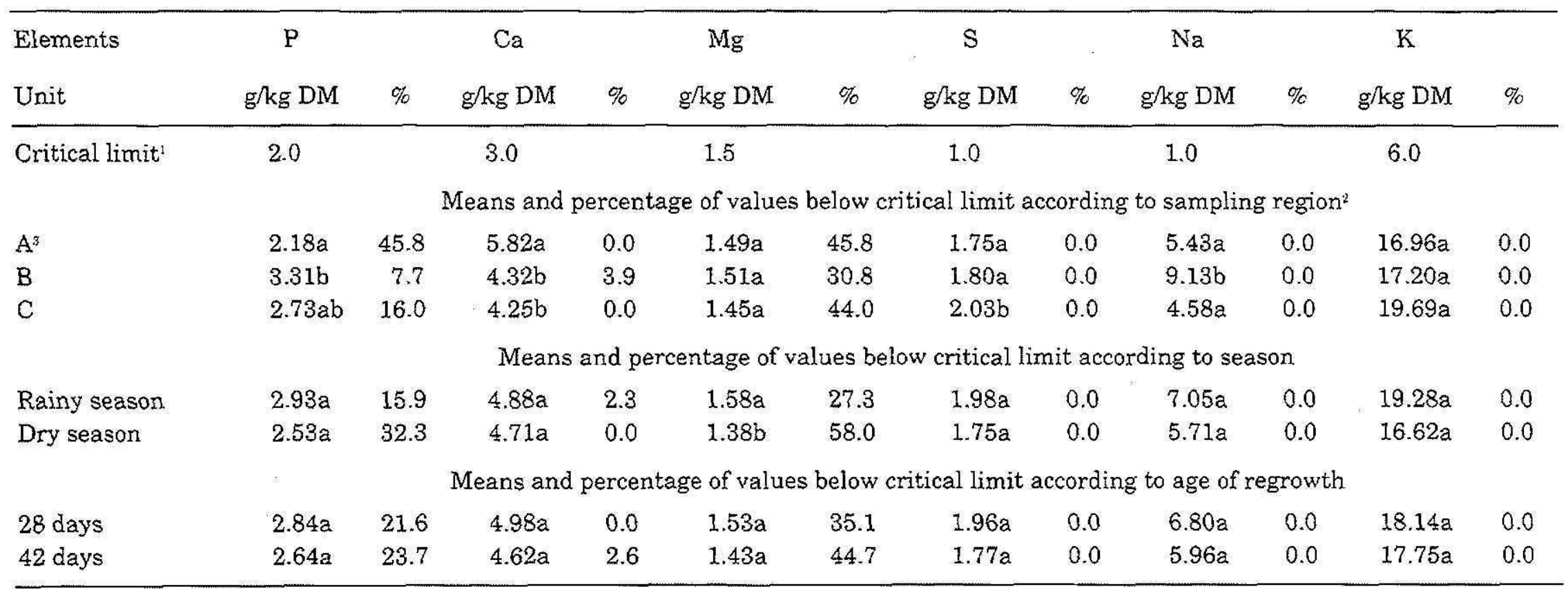

'Critical limits from Guegen \& Lamand (1980) and Underwood (1981).

'See Table 1 for the soil climate complex of each region.

${ }^{3} \mathrm{Means}$ in same column within source of variation with unlike subscripts significantly differ $(\mathrm{P}=0.01$ ). 
TABLE 3.-Trace element contents of Digitaria decumbens collected in Guadeloupe (F. W. I.).

\begin{tabular}{|c|c|c|c|c|c|c|c|c|c|c|c|c|c|c|}
\hline Elements & $\mathrm{Cu}$ & & $\mathrm{Zn}$ & & $\mathrm{Mn}$ & & Co & & $\mathrm{Se}$ & & I & & Mo & \\
\hline Units & $\mathrm{mg} / \mathrm{kg} \mathrm{DM}$ & $\%$ & $\mathrm{mg} / \mathrm{kg} \mathrm{DM}$ & $\%$ & $\mathrm{mg} / \mathrm{kg} \mathrm{DM}$ & $\%$ & $\mathrm{mg} / \mathrm{kg} \mathrm{DM}$ & $\%$ & $\mathrm{mg} / \mathrm{kg} \mathrm{DM}$ & $\%$ & $\mathrm{mg} / \mathrm{kg} \mathrm{DM}$ & $\%$ & $\mathrm{mg} / \mathrm{kg} \mathrm{DM}$ & $\%$ \\
\hline \multicolumn{15}{|l|}{ Critical } \\
\hline \multirow[t]{2}{*}{ limit } & 7.0 & & 30.0 & & 30.0 & & 0.1 & & 0.1 & & 0.1 & & - & \\
\hline & \multicolumn{14}{|c|}{ Means and percentage of values below critical limit according to sampling region ${ }^{2}$} \\
\hline $\mathrm{A}^{3}$ & $6.75 \mathrm{a}$ & 41.7 & $26.82 \mathrm{a}$ & 54.2 & $53 a$ & 12.5 & $0.21 \mathrm{a}$ & 0.0 & $0.11 \mathrm{a}$ & 33.3 & $0.44 \mathrm{a}$ & 0.0 & $1.06 \mathrm{a}$ & - \\
\hline $\mathrm{B}$ & $8.75 b$ & 19.2 & $50.40 \mathrm{~b}$ & 3.9 & $226 b$ & 0.0 & $0.21 \mathrm{a}$ & 3.9 & $0.17 \mathrm{a}$ & 19.2 & $0.54 \mathrm{a}$ & 0.0 & $0.79 a$ & - \\
\hline \multirow[t]{2}{*}{$\mathrm{C}$} & $7.69 \mathrm{ab}$ & 24.0 & $32.75 a$ & 20.0 & $284 b$ & 0.0 & $0.19 a$ & 0.0 & $0.15 \mathrm{a}$ & 20.0 & $0.46 \mathrm{a}$ & 0.0 & $0.83 a$ & - \\
\hline & \multicolumn{14}{|c|}{ Means and percentage of values below critical limit according to season } \\
\hline Rainy season & $8.59 a$ & 18.2 & $33.72 \mathrm{a}$ & 25.0 & $130 \mathrm{a}$ & 2.3 & $0.23 a$ & 0.0 & $0.14 a$ & 22.7 & $0.38 \mathrm{a}$ & 0.0 & $0.94 \mathrm{a}$ & 一 \\
\hline \multirow[t]{2}{*}{ Dry season } & $6.6 \mathrm{~b}$ & 41.9 & $37.10 \mathrm{a}$ & 25.8 & $172 \mathrm{a}$ & 6.5 & $0.18 \mathrm{~b}$ & 3.2 & $0.13 a$ & 25.8 & $0.61 \mathrm{a}$ & 0.0 & $0.83 \mathrm{a}$ & - \\
\hline & \multicolumn{14}{|c|}{ Means and percentage of values below critical limit according to ages of regrowth } \\
\hline 28 days & $8.08 a$ & 24.3 & $34.10 \mathrm{a}$ & 24.3 & $153 a$ & 2.7 & $0.21 \mathrm{a}$ & 0.0 & $0.16 \mathrm{a}$ & 10.8 & $0.52 \mathrm{a}$ & 0.0 & $0.99 a$ & - \\
\hline 42 days & $7.39 a$ & 31.6 & $36.59 \mathrm{a}$ & 26.3 & $148 a$ & 5.26 & $0.20 \mathrm{a}$ & 2.6 & $0.12 \mathrm{a}$ & 36.8 & $0.44 a$ & 0.0 & $0.80 \mathrm{a}$ & - \\
\hline
\end{tabular}

'Critical limits from Guegen \& Lamand (1980) and Underwood (1981).

"See Table 1 for the soil climate complex of each region.

${ }^{3}$ Means in the same column within source of variation with unlike subscripts significantly differ $(P=0.01)$. Means are given after exponential reconversion of the logarithm transformed variable. 
no such lows were recorded for $\mathrm{Ca}, \mathrm{S}, \mathrm{Na}$, and $\mathrm{K}$ contents of pangola (Table 2). Region of sampling was the main source of variation of the trace element contents of Digitaria decumbens. Copper and Zn contents of the samples collected in region $B$ were higher than those of the other regions ( $\mathrm{P}=0.01$; Table 3 ). The $\mathrm{Mn}$ contents of the samples collected in region $\mathrm{A}$ were lower than those of the other regions ( $\mathrm{P}=0.01$; Table 3 ).

The least square means of the macro mineral and trace element contents are shown in Tables 4 and 5 for the interaction "region of sampling" $x$ "nature of forage". This interaction was the main source of variation. Similar effects of the region of sampling on macro mineral content were recorded for pangola samples and savana samples, i.e., higher $\mathrm{Ca}$ but lower $\mathrm{P}$ contents of samples collected in region $\mathrm{A}$ than those of the other regions ( $\mathrm{P}=0.01$; Table 4$)$. However, $\mathrm{P}$ content of savana samples collected in region $B$ remained low, whereas $P$ was bigh in pangola samples. There was a marked effect of the forage type on macro mineral content, $\mathrm{P}, \mathrm{Ca}, \mathrm{Na}$ and $\mathrm{K}$ levels in savana samples were lower than those in pangola samples. In region $\mathrm{C}$, the savana samples had higher $\mathrm{Mg}$ and sulphur contents than pangola samples $(\mathrm{P}=0.01$; Table 4). The percentages of values below the $\mathrm{P}$ and $\mathrm{Mg}$ critical limits were high for savana samples, particularly in region A (Table 4). The percentages of $\mathrm{Cu}, \mathrm{Zn}$ and Se values below the critical limit were high for savana samples.

Similar effects of sampling regions on trace element content were recorded for pangola samples and savana samples, i.e., higher $\mathrm{Cu}$ and $\mathrm{Zn}$ contents in samples collected in region B and lower Mn contents for samples collected in region $A$ than those of the other regions $(P=0.01$; Table 5). The $\mathrm{Cu}$ and $\mathrm{Zn}$ contents of savanas were lower than those of pangola in regions $\mathrm{A}$ and $\mathrm{B}(\mathrm{P}=0.01$; Table 5$)$. In region $\mathrm{B}$, the $\mathrm{Mn}$ content of savana was lower than that of pangola $(\mathrm{P}<0.01$; Table 5$)$.

\section{DISCUSSION}

In most animal husbandry enterprises of the Caribbean basin, forages are the principal source of minerals for livestock, which include nursing cows and their calves, weaned calves, steers, bulls, and small ruminants of smaller yield. Our discussion refers principally to these types of animals. Although critical nutritional limits were sometimes difficult to define, the frequency of data below these limits was computed to interpret the results in contents of ruminant production purposes. Many authors have claimed important influences of plant age, soil characteristics and plant species on the mineral composition of tropical forages (McDowell et al., 1985; Minson, 1990; Underwood, 1981.). 
TABLE 4.-Macro mineral contents of forages (Digitaria decumbens vs. natural savana) collected in Guadeloupe (F. W. I.).

\begin{tabular}{|c|c|c|c|c|c|c|c|c|c|c|c|c|c|}
\hline Elements & & $\mathrm{P}$ & & $\mathrm{Ca}$ & & $\mathrm{Mg}$ & & $\$$ & & $\mathrm{Na}$ & & $\mathrm{K}$ & \\
\hline Units & & g/kg DM & $\%$ & $\mathrm{~g} / \mathrm{kg} \mathrm{DM}$ & $\%$ & $\mathrm{~g} / \mathrm{kg} \mathrm{DM}$ & $\%$ & $\mathrm{~g} / \mathrm{kg} \mathrm{DM}$ & $\%$ & $\mathrm{~g} / \mathrm{kg} \mathrm{DM}$ & $\%$ & $\mathrm{~g} / \mathrm{kg} \mathrm{DM}$ & $\%$ \\
\hline Critical limit & & 2.0 & & 3.0 & & 1.5 & & 1.0 & & 1.0 & & 6.0 & \\
\hline \multirow[t]{2}{*}{ Region $\mathrm{A}^{2}$} & Pangola & $2.14 \mathrm{ab}$ & 45.8 & $5.78 \mathrm{a}$ & 0.0 & $1.48 \mathrm{a}$ & 45.8 & $1.66 \mathrm{a}$ & 0.0 & $5.41 \mathrm{a}$ & 0.0 & $17.01 a c$ & 0.0 \\
\hline & savana & $1.35 b$ & 85.7 & $7.33 b$ & 0.0 & $1.39 a$ & 57.1 & $1.85 \mathrm{a}$ & 0.0 & $0.65 c$ & 85.7 & $9.64 b$ & 21.4 \\
\hline \multirow[t]{2}{*}{ Region $\mathrm{B}$} & Pangola & $3.39 c$ & 7.7 & $4.38 \mathrm{~cd}$ & 3.9 & $1.51 \mathrm{a}$ & 30.8 & $1.78 \mathrm{a}$ & 0.0 & $9.03 \mathrm{~b}$ & 0.0 & $16.80 \mathrm{a}$ & 0.0 \\
\hline & savana & $1.50 \mathrm{~b}$ & 75.0 & $5.45 a c$ & 0.0 & $1.25 \mathrm{a}$ & 75.0 & $1.59 \mathrm{a}$ & 0.0 & $1.30 \mathrm{c}$ & 25.0 & $10.28 \mathrm{~b}$ & 25.0 \\
\hline \multirow[t]{2}{*}{ Region C } & Pangola & $2.71 b c$ & 16.0 & $4.24 \mathrm{~cd}$ & 0.0 & $1.46 \mathrm{a}$ & 44.0 & $1.94 \mathrm{a}$ & 0.0 & $4.63 \mathrm{a}$ & 0.0 & $19.84 \mathrm{ac}$ & 0.0 \\
\hline & savana & $2.31 b$ & 30.0 & $3.43 \mathrm{~d}$ & 20.0 & $2.98 b$ & 0.0 & $5.01 b$ & 0.0 & $0.93 c$ & 50.0 & $21.52 \mathrm{c}$ & 0.0 \\
\hline
\end{tabular}

Critical limits from Guegen \& Lamand (1980) and Underwood (1981).

${ }^{2}$ Means in the same column within source of variation with unlike subscripts significantly differ $(P=0.01)$. 
TABLE 5.-Trace element contents of forages (Digitaria decumbens vs. natural savana) collected in Guadeloupe (F. W. I.).

\begin{tabular}{|c|c|c|c|c|c|c|c|c|c|c|c|c|c|c|c|}
\hline Elements & & $\mathrm{Cu}$ & & $\mathrm{Zn}$ & & $\mathrm{Mn}$ & & Co & & $\mathrm{Se}$ & & I & & Mo & \\
\hline Unit & & $\mathrm{mg} / \mathrm{kg} \mathrm{DM}$ & $\%$ & $\mathrm{mg} / \mathrm{kg} \mathrm{DM}$ & $\%$ & $\mathrm{mg} / \mathrm{kg} \mathrm{DM}$ & $\%$ & $\mathrm{mg} / \mathrm{kg} \mathrm{DM}$ & $\%$ & $\mathrm{mg} / \mathrm{kg} \mathrm{DM}$ & $\%$ & $\mathrm{mg} / \mathrm{kg} \mathrm{DM}$ & $\%$ & $\mathrm{mg} / \mathrm{kg} \mathrm{DM}$ & $\%$ \\
\hline \multicolumn{16}{|l|}{ Critical } \\
\hline $\operatorname{limit}^{1}$ & & 7.0 & & 30.0 & & 30.0 & & 0.1 & & 0.1 & & 0.1 & & - & \\
\hline Region $\mathrm{A}^{2}$ & Pangola & $6.75 a$ & 41.7 & $26.29 a$ & 54.2 & $52 a$ & 12.5 & $0.21 a$ & 0.0 & $0.11 a$ & 33.3 & $0.44 \mathrm{a}$ & 0.0 & $1.06 \mathrm{a}$ & - \\
\hline \multirow[t]{2}{*}{ Region B } & Pangola & $8.66 \mathrm{~b}$ & 19.2 & $51.42 \mathrm{c}$ & 3.9 & $223 \mathrm{~b}$ & 0.0 & $0.21 a$ & 3.9 & $0.17 a$ & 19.2 & $0.56 \mathrm{ab}$ & 0.0 & $0.79 \mathrm{a}$ & - \\
\hline & Savana & $5.40 \mathrm{a}$ & 75.0 & $26.23 a b$ & 75.0 & $63 a$ & 0.0 & $0.18 a$ & 0.0 & $0.40 \mathrm{a}$ & 0.0 & $0.90 \mathrm{~b}$ & 0.0 & $0.98 a$ & - \\
\hline \multirow[t]{2}{*}{ Region C } & Pangola & $7.81 \mathrm{~b}$ & 24.0 & $32.94 b$ & 20.0 & $287 \mathrm{~b}$ & 0.0 & $0.19 a$ & 0.0 & $0.15 a$ & 20.0 & $0.46 a$ & 0.0 & $0.83 \mathrm{a}$ & - \\
\hline & Savana & $7.25 \mathrm{ab}$ & 40.0 & $38.24 b$ & 0.0 & $387 \mathrm{~b}$ & 0.0 & $0.22 a$ & 0.0 & $0.11 \mathrm{a}$ & 30.0 & $0.78 \mathrm{~b}$ & 0.0 & $0.47 a$ & - \\
\hline
\end{tabular}


The Ca requirements of interest range from 2.0 to $6.0 \mathrm{~g} / \mathrm{kg} \mathrm{DM}$, and $\mathrm{P}$ requirements from 1.8 to $4.0 \mathrm{~g} / \mathrm{kg}$ DM (Guegen and Lamand, 1980; NRC, 1984). A Ca/P ratio ranging from 0.5 to 2.0 and a Ca intake lower than $3.0 \mathrm{~g} / \mathrm{kg}$ DM is desirable for dairy cows to prevent milk fever (Goings et al., 1974). The $\mathrm{Ca}$ and $\mathrm{P}$ contents of Digitaria decumbens samples were similar to those reported by Salette et al. (1973) in Guadeloupe and Wilson et al. (1981) for grasses grown on Ca-dominated Caribbean soils. Frequency of forages with a Ca content below the critical limit $(3.0 \mathrm{~g} / \mathrm{kg} \mathrm{DM})$ was low, whereas the frequency of forages with a $\mathrm{P}$ content below the $2.0 \mathrm{~g} / \mathrm{kg}$ DM limit was high, particularly for natural pasture forages grown on Vertisols $(85.4 \%)$. Thus, in Guadeloupe, whatever the diet is based on, careful attention must be given to the $\mathrm{P}$ dietary intake of ruminants. Furthermore, since the Ca content of forages is high, a $\mathrm{P}$ supplement without $\mathrm{Ca}$ is recommended for preparturient dairy cows, particularly in the calcareous Caribbean islands.

The $\mathrm{Mg}$ requirements of cattle range between 1.5 and $2.5 \mathrm{~g} / \mathrm{kg} \mathrm{DM}$ (Guegen and Lamand, 1980; NRC, 1978, 1984). The Mg content of forages that we analyzed was higher than those recorded by Tejada et al. (1985) in Guatemala (1.09 $\mathrm{g} / \mathrm{kg} \mathrm{DM})$. However, it was similar to those recorded by Salette et al. (1973), i.e. $1.4 \mathrm{~g} / \mathrm{kg}$ DM. The marked effect of the region of sampling found in this study was due to a high $\mathrm{Mg}$ content in the natural pastures grown on very acid soils (Oxisols) of region C. The minor effects of the region of sampling factor on $\mathrm{Mg}$ content of pangola samples has already been reported (Salette et al., 1973). Mg deficiencies have already been reported in tropical countries and in Haiti, Trinidad and Jamaica (McDowell, 1976). This fact suggests that a supplemental Mg supply would be beneficial for dairy cows produced in these areas. However, the prevalence of hypomagnesemic tetany is probably lower in warm countries than in temperate ones, because of the great importance of environmental factors such as cold, seasonal grazing and seasonal dry feeding in the etiology of this disease in temperate climates (Rayssiguier et al., 1981). For nursing cows and bulls fed pangola grass, clinical $\mathrm{Mg}$ deficiency would be unlikely since the frequency of forage $\mathrm{Mg}$ content below $1.0 \mathrm{~g} / \mathrm{kg} \mathrm{DM}$ was lower than $4 \%$.

The Na contents of pangola samples was 10 fold higher than those of the natural pasture forages. Such high Na content for pangola grass has been reported elsewhere (Salette et al., 1973), although these authors have not recorded any effect of soil properties on the $\mathrm{Na}$ content of pangola grass. The $\mathrm{Na}$ content of the natural pasture samples was similar to that recorded by McDowell et al. (1977) on Latin American forages and by Wilson et al. (1981) on grass from Caribbean lands (60\% 
of the Na content of forage was below $1.0 \mathrm{~g} / \mathrm{kg} \mathrm{DM}$ ). The fact that there was some pangola grass in the natural pastures of region $\mathrm{B}$ could explain why the $\mathrm{Na}$ content of the natural pasture samples from this area was higher than those from the other areas. The $\mathrm{K}$ content of the pangola samples agreed with those already reported (Gomide et al., 1969; Salette et al., 1973; Tejada et al., 1985), i.e. considerably higher than the $6.0 \mathrm{~g} / \mathrm{kg}$ of DM of the critical nutritional limit. Thus $\mathrm{K}$ deficiency is unlikely in the grazing ruminants of the French West Indies.

Ruminant requirements of S range from 1.0 to $2.0 \mathrm{~g} / \mathrm{kg}$ DM (Elam, 1975; Guegen and Lamand, 1980; Underwood, 1981). The S nutrition of ruminants derives both from mineral nutrition and $\mathrm{N}$ metabolism (amino acid synthesis in ruminants). Therefore, the availability of $\mathrm{S}$ from different sources, the nitrogen/sulphur ratio, the nitrogen solubility and the interactions between $\mathrm{Cu}, \mathrm{Mo}$ and $\mathrm{S}$ for Mo contents above $3.0 \mathrm{~g} / \mathrm{kg} \mathrm{DM}$, all these are possibly important factors of variation in $\mathrm{S}$ requirements. Assuming that there is no interaction, the $1.0 \mathrm{~g} \mathrm{~S} / \mathrm{kg} \mathrm{DM}$ level was chosen as the critical limit for $\mathrm{S}$. The $\mathrm{S}$ contents of samples were largely above the critical limit. The $\mathrm{S}$ content recorded in our study was similar to that reported for Panicum maximum grown on lateritic podzolic soil (Smith and Dolby, 1977). No major disorders are expected to result from the high $\mathrm{S}$ content. However, it must be noted that for cattle fed with diets based on molasses plus urea, $\mathrm{S}$ addition would be required (Preston and leng, 1986).

The soil-climate complexes were less important sources of variation for trace elements content in plants than of macro minerals. The discrepancies between trace element content of plants and the chemical composition of the soil have been noted elsewhere (McDowell et al., 1985; Tejada et al., 1985; Underwood, 1981). The $\mathrm{Cu}, \mathrm{Zn}$ and Se contents of forages were generally low. There were high frequencies of concentrations below the trace element critical limits. The low $\mathrm{Cu}$ and $\mathrm{Zn}$ contents of forages were more frequent for natural pasture in region A (calcarous soils) during the dry season. The extent of $\mathrm{Cu}$ and $\mathrm{Zn}$ deficiencies in sheep and goats on the Caribbean islands has already been reported by Youssef (1985) and McDowell (1976). Se deficiencies have also been noted in cattle and calves grazing on calcareous lands with marked dry season (Wilson et al., 1981), and on other Caribbean lands (McDowell, 1976). However, further clinical and biochemical studies are required to confirm the importance of $\mathrm{Cu}, \mathrm{Zn}$ and Se deficiency in ruminants in Guadeloupe. The possible resistance of local breeds to trace element imbalances might be an important factor in adaptation to environmental conditions.

The effects of soil $\mathrm{pH}$ on the $\mathrm{Mn}$ availability for uptake by plants are well documented (Minson, 1990; Underwood, 1981). Soil pH may be the 
cause of the large differences between the Mn content of forage grown in region $\mathrm{A}$ and that grown in regions $\mathrm{B}$ and $\mathrm{C}$. However, the $\mathrm{Mn}$ contents of forages from region $\mathrm{A}$ was higher than those recorded by Wilson et al. (1981) on grasses grown on Bahamas calcareous soil. The Mn values were markedly above the $30 \mathrm{mg} / \mathrm{kg} \mathrm{DM}$ critical limit. Mn deficiencies in ruminants therefore seem unlikely in the French West Indies. The same conclusion for $\mathrm{Co}$ and I could be drawn from our results. The variability of I content of forages was largely explained by plant species and seasonal differences. Such effects have already been reported for temperate pastures (Hartman, 1974).

\section{CONCLUSIONS}

The Guadeloupe islands offer a variety of soil-climate complexes that are encountered in the French West Indies and other Caribbean countries. From our results, it appears that definition of the soil-climate complexes based on pH, cation exchangeable capacity (C.E.C.), P solubility, and annual rainfall could be helpful in adopting a strategy for dietary mineral supplies for ruminants in Caribbean areas. These data are in agreement with other data based on published compilations (McDowell et al., 1985; Minson, 1990; Reid and Horvath, 1980; Underwood, 1981). Both soil-climate complex and plant species appeared to be the main sources of variation, whereas age of regrowth was of minor importance for all elements. The P deficiency risk, for all types of ruminant, was high in all types of soil, and plant species. Except for volcanic originated soil, S supplies would be required for diets based on molasses plus urea. $\mathrm{Cu}, \mathrm{Zn}$ and Se were the most deficient trace elements in pastures in terms of ruminant feeding. By contrast, $\mathrm{Mn}, \mathrm{Co}$ and I deficiencies in livestock would be unlikely in Guadeloupe. Nonetheless, further clinical and experimental studies on animals are required to confirm these conclusions.

\section{LITERATURE CITED}

Bellangex; J., 1971. Dosage des oligoéléments dans les fourrages. Annales de Nutrition et d'Alimentation, 25:B59-B96.

Bellanger, J., J. C. Tressol and H. Piel, 1979. A semi-automated method for the determination of iodine in plants. Annales de Recherches Vétérinaires, 10:113-118.

Colmet-Daage, F. and P. Lagache, 1969. Aperçu sur les sols des Antilles. In: "Proc. of the 7th Symposium of the Caribbean Food Crops Society" (Guadeloupe, Martinique), 7:242-250.

Duval, L., 1971. Le dosage de molybdène dans les végétaux. Examen de divers procédés de détermination. Mise au point d'une méthode colorimétrique au thiocyanate. Annales d'Agronomie, 22:127-147.

Elam, C. J., 1975. Sulfur requirements of ruminants. Feedstuffs, 47:23-25 \& 48.

Fournet, J. and P. Monestiez, 1987. Essai de caractérisation phytoécologique des formations herbacées pâturées de Grande-Terre (Guadeloupe). Agronomie, 7:833-851. 
Goings, R. L., N. L. Jacobson, D. C. Beitz and E. T. Littledike, 1974. Prevention of parturient paresis by a prepartum calcium deficient diet. Journal of Dairy Science, 56:672.

Gomide, J. A., C. H. Noller, G. O. Mott, J. H. Conrad and D. L. Hill, 1969. Mineral composition of six tropical grasses as influenced by plant age and nitrogen fertilization. Agronomy Journal, 61:120-123.

Guegen, L. and M. Lamand, 1980. Les minéraux. In: L'alimentation des ruminants, pp. 129-142, 2nd edition, INRA publication (ed.), Versailles (France).

Hartman, J., 1974. Factors affecting the herbage iodine content. Netherlands Journal of Agriculture Science, 22:195-206.

Hocquellet, P., 1974. Dosage du cobalt dans les aliments des animaux par spectrometrie d'absorption atomique avec flamme et sans flamme. Annales de Falsification et de l'Expertise Chimique, 67:495-511.

Lamand, M., 1969. Dosage du sélénium dans les produits biologiques et les mélanges minéraux alimentaires. Annales de Falsification et de l'Expertise Chimique, 62;412.

McDowell, L. R., 1976. Mineral deficiencies and toxicities and their effect on beef production in developing countries. In: Beef Cattle production in developing countries, pp. 216-241, Smith, A. J. (ed.), Centre for Tropical Veterinary Medicine. Edinburg.

McDowell, L. R., J. H. Conrad, J. E. Thomas, L. E. Harris and K. R. Fick, 1977. Nutritional composition of latin american forages. Tropical Animal Production, 2:273279 .

McDowell, L. R., J. H. Conrad and G. L. Ellis, 1985. Soil-plant relationships as determinants of the geographical distribution of trace elements related diseases in animals. In: Trace Elements Metabolism in Animals. 5th Symposium, pp. 911-913, Mills, C. F., I. Bremmer \& J. K. Chester (eds.), Commonwealth Agricultural Bureaux.

Minson, D. J., 1990. Forage in ruminant nutrition. Cunha, T. J. (ed.), Academic press (New York).

N. R. C., 1978. Nutrient requirements of domestic animals, 3. Nutrient requirements of dairy cow (5th ed.). National Academy of Sciences, National Research Council, Washington, D.C.

N. R. C., 1984. Nutrient requirements of domestic animals. 4. Nutrient requirements of beef cattle (6th ed.). National Academy of Sciences. National Research Council, Washington, D.C.

Osburn, D. F, 1976. Mineral nutrition of beef cattle. In: Beef cattle production in developing countries. pp. 184-203, Smith, A. J. (ed.), Centre for Tropical Veterinary Medicine, Edinburg.

Preston, T. R. and R. A. Leng, 1986. Matching livestock production systems to available resources. Pretesting edition, ILCA edition, pp. 331.

Rayssiguier, Y., C. Demigne and C. Remesy, 1981. Milieux et maladies métaboliques. In: Pathologie et Prévention chez les Ruminants, pp. 175-183, INRA publication (ed.), Versailles, France.

Reid, R. L. and D. J. Horvath, 1980. Soil chemistry and mineral problems in farm livestock. A review. Animal and Feed Science Technology, 5:95-166.

Salette, J. E., Y. Dumas and O. Sobesky, 1973. Données sur les éléments minéraux chez Digitaria decumbens cultivé dans divers milieux. Agronomie Tropicale, 26:833-845.

SAS, 1987. SAS User's guide. Statistics. Ed. SAS Institute Inc., Cary, North Carolina.

Smith, F. W. and G. R. Dolby, 1977. Derivation of diagnostic indices for assessing the sulphur status of Panicum maximum var. Trichlogume. Communications in Soil Science and Plant Analysis, 8:221-240. 
Tejada, R., L. R. McDowell, F, G. Martin and J. H. Conrad, 1985. Mineral element analyses of various tropical forages in Guatemala and their relationship to soil concentration. Nutrition Reports International, 32;313-324.

Underwood, E. J. 1981. The mineral nutrition of livestock. Commonwealth Agxicultural Bureaux, London.

Wilson, L. L., D. D. Fisher and T. S. Katsigianis, 1981. Mineral composition of tropical forages and metabolic blood profiles of grazing cattle and sheep on calcium-dominated Caribbean soils. Tropical Agriculture, 58:53-61.

Youssef, F. G., 1985. A preliminary mineral blood profile of tropical goats and sheep in Trinidad. In: Trace Elements Metabolism in Animals, 5th Symposium, pp. 857-859, Mills, C. F., I. Bremner \& J. K. Chester (eds.), Commonwealth Agricultural Bureaux. 